\title{
Fish protein hydrolysate in diets for Nile tilapia post-larvae
}

\author{
Thiberio Carvalho da Silva(1), Joana D'Arc Mauricio Rocha(1), Pedro Moreira(1), \\ Altevir Signor ${ }^{(1)}$ and Wilson Rogerio Boscolo ${ }^{(1)}$
}

(1)Universidade Estadual do Oeste do Paraná, Campus Toledo, Rua da Faculdade, no 2.550, CEP 85903-000 Toledo, PR, Brazil. E-mail: thiberiocs@hotmail.com, joanadmrocha@hotmail.com, pedro-mv2011@hotmail.com, altevir.signor@gmail.com, wilsonboscolo@hotmail.com

\begin{abstract}
The objective of this work was to determine the apparent digestibility coefficient (ADC) of crude protein, crude energy, fat, and dry matter of fish protein hydrolysate (FPH), made of by-products of Nile tilapia (Oreochromis niloticus) and whole sardines (Cetengraulis edentulus), and to evaluate the productive performance and muscle fiber growth of Nile tilapia post-larvae. Two trials were conducted, the first one to determine the digestibility in 120 fingerlings $(70.0 \pm 2.0 \mathrm{~g})$, and the second one to evaluate the productive performance of 375 post-larvae, with three days of age, which were distributed in 25 aquaria with $30 \mathrm{~L}$ of useful volume. Five diets were prepared based on vegetable ingredients, to which fish were included at 0,2 , 4,6 , and $8 \% \mathrm{FPH}$. For the evaluation of muscle growth, eight fish of each experimental unit were used. The ADC values found were: $98.29 \%$ for dry matter; $99.28 \%$ for crude protein; and $99.13 \%$ for gross energy. The best zootechnical response for the productive performance resulted from the treatment with the inclusion of fish hydrolysate at $4.75 \%$. The diets affected the frequency of the muscle fiber diameters, mainly the growth by hyperplasia. FPH can be efficiently used, and its inclusion at $4.75 \%$ is indicated in the diets for Nile tilapia in the post-larvae stage.

Index terms: Cetengraulis edentulus, Oreochromis niloticus, digestibility, fish meal, nutrition, peptides, pisciculture.
\end{abstract}

\section{Hidrolisado proteico de peixe em dietas para pós-larvas de tilápia-do-nilo}

\begin{abstract}
Resumo - O objetivo deste trabalho foi determinar o coeficiente de digestibilidade aparente (CDA) da proteína bruta, da energia bruta, da gordura e da matéria seca de um hidrolisado proteico de peixe (HPP), feito de resíduos de tilápia-do-nilo (Oreochromis niloticus) e sardinha inteira (Cetengraulis edentulus), e avaliar o desempenho produtivo e o crescimento das fibras musculares de pós-larvas de tilápia-do-nilo. Realizaram-se dois ensaios, o primeiro para a determinação da digestibilidade em 120 alevinos $(70,0 \pm 2,0 \mathrm{~g})$ e, o segundo, para avaliação do desempenho produtivo de 375 pós-larvas, com três dias de idade, distribuídas em 25 aquários (unidade experimental) com volume útil de $30 \mathrm{~L}$. Cinco rações à base de ingredientes vegetais foram elaboradas, às quais se incluíram os peixes a $0,2,4,6$ e $8 \%$ de HPP. Para a avaliação do crescimento muscular, oito peixes de cada unidade experimental foram utilizados. Os valores de CDA encontrados foram: 98,29\% para matéria seca; 99,28\% para proteína bruta; e 99,13\% para energia bruta. As melhores respostas zootécnicas quanto ao desempenho produtivo resultaram do tratamento com a inclusão do hidrolisado proteico a $4,75 \%$. As dietas influenciaram a frequência do diâmetro das fibras musculares, principalmente o crescimento por hiperplasia. O HPP pode ser eficientemente utilizado, e sua inclusão a 4,75\% é indicada em dietas de tilápia-do-nilo na fase de pós-larva.
\end{abstract}

Termos para indexação: Cetengraulis edentulus, Oreochromis niloticus, digestibilidade, farinha de peixe, nutrição, peptídeos, piscicultura.

\section{Introduction}

The production of larvae and fry in the quantity and quality to meet the growing demand of fish farming depends on efficient solutions to problems in the rearing process. Feeding outstands as the main factor among those responsible for failures in larviculture, (Phelps, 2010).
To achieve satisfactory performance indices, it is recommended that, in the initial stage, part of the dietary protein be of animal origin because of the better profile of available amino acids and minerals (Galdioli et al., 2000; NRC, 2011). Therefore, fish meal continues to be the main protein source in diets for most species of farmed fish because of the balanced amino acid profile and the composition of essential 
fatty acids, digestible energy, vitamins, and minerals (Tacon \& Metian, 2008).

However, worldwide fish meal production has staganated by approximately 6-7 million tons in recent years, and with the increasing demand, its value has increased, raising production costs in aquaculture systems (Tacon \& Metian, 2008; Merino et al., 2010). Therefore, several studies have been conducted on the total or partial replacement of fish meal in the preparation of diets for aquatic organisms, in order to maintain the nutritional standards of the feeds (Teixeira et al., 2006).

An alternative with great potential is the use of byproducts of the fish-processing industry, in the form of protein hydrolysate and fish of low-commercial value. The hydrolysis process is defined as the protein breakdown into peptides of various sizes. This breakdown can be achieved chemically (with acids or bases), or biologically (with enzymes). The enzymatic process is more promising, as it generates a product with high functionality and nutritional value (Naylor et al., 2009; Pasupuleti \& Braun, 2010).

The composition of a protein hydrolysate, produced from fish residue, may contain on average $78.75 \%$ crude protein, $3.42 \%$ fat, and $12.51 \%$ ash (Nilsang et al., 2005). The partial replacement of the fish meal with this product, even at low percentages, shows a beneficial effect on the productive performance and immunological activity of several fish species, mainly in the early stages of life (Refstie et al., 2004; Hevroy et al., 2005).

Tang et al. (2008) have shown that including up to $10 \%$ fish protein hydrolysate (FPH) in the diet of yellow croaker (Pseudosciaena crocea) improved the growth and immunological parameters of this fish. Likewise, Lian et al. (2005) and Chotikachinda et al. (2013) found positive effects with FPH supplementation in the diet of the studied species. The results found in these studies may be related to the high palatability of FPH, which contains biologically active, immunestimulating peptides with antibacterial properties that can be produced during the hydrolysis process (Kotzamanis et al., 2007).

The objective of this work was to determine the apparent digestibility coefficient (ADC) of crude protein, crude energy, fat, and dry matter of FPH, made of by-products of Nile tilapia (Oreochromis niloticus) and whole sardines (Cetengraulis edentulus), and to evaluate the productive performance and muscle fiber growth of Nile tilapia post-larvae.

\section{Materials and Methods}

Digestibility and zootechnical performance trials were carried out at the aquaculture and fish nutrition laboratory of Grupo de Estudos de Manejo na Aquicultura (Gemaq), of Universidade Estadual do Oeste do Paraná (Unioeste), Campus Toledo, in the municipality of Toledo, PR, Brazil.

The production of FPH consisted of $80 \%$ residues from Nile tilapia filleting (heads, viscera, scales, fins, vertebral column, and adhered tissues) and $20 \%$ whole sardine which were used to enhance the aroma and taste of FPH, in order to improve the final product attractiveness (Broggi, 2014). This raw material was crushed in a CAF food processor, model Boca 5, 250 -watt power and $30 \mathrm{~kg} \mathrm{~h}^{-1}$ capacity; then, a water volume equivalent to $20 \%$ of the mass value was added and homogenized. The mixture was placed for approximately $5 \mathrm{~min}$ in a RW 20 mechanical stirrer (Ika Brasil Equipamentos Laboratoriais, Analíticos e Processos Ltda., Campinas, SP, Brazil). Subsequently, butylated hydroxytoluene (BHT) and butylated hydroxyanisole (BHA) were added at $0.01 \%$. The temperature was adjusted to $60^{\circ} \mathrm{C}$ in a water bath to promote the enzymatic activity. Alcalase enzyme was added at $0.5 \%$ and stirred continuously for $60 \mathrm{~min}$. After this time, the enzymatic activity was stopped by raising the temperature to $85^{\circ} \mathrm{C}$ for $15 \mathrm{~min}$, and a food preservative (citric acid) was added. At the end of the process, the liquid hydrolysate was filtered through a $0.5 \mathrm{~mm}$ steel sieve to remove small bones.

To determine digestibility, the diets were elaborated with an extruded practical feed (used as reference), and an extruded test feed composed of $80 \%$ of the reference feed and $20 \%$ of the ingredient to be tested, adding $0.1 \%$ chromium oxide, used as inert marker (NRC, 2011) (Table 1).

For the feed production, the ingredients were initially milled in a hammer-type grinder with a 0.7 $\mathrm{mm}$ sieve, and, then, weighed and mixed manually. The crushed feed was moistened with $20 \%$ water, and extruded in an ExMicro apparatus (Exteec Máquinas, Ribeirão Preto, SP, Brazil), with $10 \mathrm{~kg} \mathrm{~h}^{-1}$ production capacity. After this processing, the feeds were oven dried at $55^{\circ} \mathrm{C}$ for 12 hours. 
Nile tilapia juveniles (120) with a mean mass of $70 \pm 2 \mathrm{~g}$ were used. Fish were randomly distributed in six $90 \mathrm{~L}$ conical tanks suitable for the collection of feces. The juveniles remained in the tanks for seven days in the tanks, in order to adapt to the diets and to the experimental conditions. The treatments, randomly assigned at the beginning of the adaptive period, consisted of three tanks with reference feed, and three tanks with test feed. Fish were fed at 09:00, 12:00, 15:00, and 18:00 $\mathrm{h}$. Two hours after the last feeding, the tanks were cleaned, and $70 \%$ of the water volume was exchanged, to avoid contamination of the feces by feed debris. Finally, the collecting cups were attached to the bottom of the tanks and, at 07:00 $\mathrm{h}$ of the following day, feces were collected and immediately stored in a freezer at $-15^{\circ} \mathrm{C}$ until the start of the analyses.

The coefficients of apparent digestibility and gross energy of the nutrients in the diets and FPH were calculated according to the NRC equations (2011), adapted for $20 \%$ of the feed inclusion, as follows:

Table 1. Composition of the reference diet used for determination of the apparent digestibility coefficient (ADC) of fish protein hydrolysate (FPH).

\begin{tabular}{lc}
\hline Ingredient & Percentage (\%) \\
\hline Soybean meal & 27.51 \\
Rice meal & 25.00 \\
Corn grain & 17.87 \\
Fish meal & 15.00 \\
Wheat gluten & 8.00 \\
Poultry meal & 5.00 \\
Supplement (mineral + vitamin) ${ }^{(1)}$ & 1.00 \\
Salt & 0.30 \\
Chromium oxide & 0.10 \\
Antifungal & 0.20 \\
Antioxidant & 0.02 \\
\hline Total & 100.00 \\
\hline Calculated values & \\
Starch (\%) & 32.00 \\
Calcium (\%) & 1.26 \\
DE tilapia (kcal kg-1) & 3,118 \\
Fat (\%) & 3.12 \\
Methionine (\%) & 0.57 \\
Digestible protein (\%) & 29.73 \\
Threonine (\%) & 1.19 \\
\hline
\end{tabular}

${ }^{(1)}$ Guarantee levels by kilogram of product: 500,000 IU vitamin A; 200,000 IU vitamin D3; $5.000 \mathrm{mg}$ vitamin $\mathrm{E} ; 1,000 \mathrm{mg}$ vitamin $\mathrm{K} 3 ; 1,500$ $\mathrm{mg}$ vitamin $\mathrm{B} 1 ; 1,500 \mathrm{mg}$ vitamin $\mathrm{B} 2 ; 1,500 \mathrm{mg}$ vitamin $\mathrm{B} 6 ; 4,000 \mathrm{mg}$ vitamin $\mathrm{B} 12 ; 15,000 \mathrm{mg}$ vitamin $\mathrm{C}$; $50 \mathrm{mg}$ biotin; 7,000 $\mathrm{mg}$ nicotinamide; $500 \mathrm{mg}$ folic acid; 4,000 mg calcium pantothenate; 10,000 IU inositol; 40,000 mg choline; $10 \mathrm{mg} \mathrm{Co} ; 500 \mathrm{mg} \mathrm{Cu} ; 5, .000 \mathrm{mg} \mathrm{Fe} ; 50 \mathrm{mg} \mathrm{I} ; 1,500$ $\mathrm{mgMn} ; 10 \mathrm{mgSe}$; and 5,000 mg Zn.
$\mathrm{CDA}(\mathrm{n})=\left\{100-\left[100 \times\left(\% \mathrm{Cr}_{2} \mathrm{O}_{3} \mathrm{~d} \times \% \mathrm{Cr}_{2} \mathrm{O}_{3} \mathrm{f}\right) \times(\% \mathrm{Nf} /\right.\right.$ $\% \mathrm{Nd})]\}$, in which: $\mathrm{CDA}(\mathrm{n})$ is the nutrient digestibility coefficient; $\% \mathrm{Cr}_{2} \mathrm{O}_{3} \mathrm{~d}$ is the percentage of chromium oxide in the diet; $\% \mathrm{Cr}_{2} \mathrm{O}_{3} \mathrm{f}$ is the percentage of chromium oxide in feces; $\% \mathrm{Nf}$ is the percentage of nutrient in feces; $\% \mathrm{Nd}$ is the percentage of nutrient in the diet. And CDA (i) $=\{$ CDAdt $+[$ (CDAdt - CDAdr $)$ $\times(0.8 \times$ Ddr / $0.2 \times$ Ding $)]\}$, in which: CDA (i) is the apparent digestibility coefficient of the ingredient; 0.8 is the percentage of the reference diet; CDAdt is the apparent digestibility coefficient of the test diet; 0.2 is the percentage of the ingredient; and CDAdr is the apparent digestibility coefficient of the reference diet.

The reference feed and the test feed were analyzed for dry matter, ash, crude protein, fat, energy, and chromium oxide. The following components of the feces were analyzed: crude protein, gross energy, fat, and chromium oxide. The analyses of the diets and feces followed the methodology described by Horwitz (2005), except for the chromium analysis that followed the protocol described by Bremer Neto et al. (2003).

The zootechnical performance of Nile tilapia postlarvae was evaluated in 375 three-day-old Nile tilapia post-larvae, which were distributed in 25 aquaria of $30 \mathrm{~L}$ useful volume each, in a completely randomized design, with five treatments and five replicates, in which the experimental unit consisted of an aquarium with 15 animals. Each aquarium had its own water aeration and heating system. The aquaria were siphoned twice a day: once in the morning and again in the late afternoon. Fish were fed at 08:00, 10:00, 12:00, 14:00, and 18:00 h. The experiment lasted 40 days.

Five feeds were prepared based on ingredients of plant origin, with five different percentages of FPH: $0,2,4,6$, and $8 \%$. The experimental diets were formulated according to the NRC recommendation (2011) (Table 2). The feeds were extruded according to the procedure described for the digestibility trial; however, shortly after drying, the feeds were ground again to obtain a $0.7 \mathrm{~mm}$ feed.

At the end of the experimental period, fish were fasted for 24 hours, then the individual measurements of mass $(\mathrm{g})$ and total length $(\mathrm{cm})$ were recorded. The evaluated zootechnical performance variables were: final mass, mass gain, specific growth rate, protein efficiency rate, survival rate, and batch uniformity.

In both experiments, the water temperature, dissolved oxygen, and $\mathrm{pH}$ were measured daily using a 
HI 9828 multi-parameter (Hanna Instruments Portugal Ltda., Póvoa de Varzim, Portugal) and remained within the recommended amounts for the species cultivation (Ridha \& Cruz, 2001). The average values obtained in the digestibility trial were: temperature, $25.12^{\circ} \mathrm{C} \pm 1.15^{\circ} \mathrm{C}$; dissolved oxygen, $4.55 \pm 0.64 \mathrm{mg} \mathrm{L}^{-1}$; and $\mathrm{pH}, 6.68 \pm 0.26$. The average values obtained in the zootechnical performance test were: water temperature, $26.26^{\circ} \mathrm{C} \pm 0.50^{\circ} \mathrm{C}$; dissolved oxygen, $5.93 \pm 0.34 \mathrm{mg} \mathrm{L}^{-1}$; and $\mathrm{pH}, 6.23 \pm 0.40$.

In the morphometric analyses of muscle fiber, eight fish from each experimental unit were used to evaluate muscle growth. These samples were fixed in $10 \%$ buffered formalin for 24 hours, and processed for inclusion in paraffin. Cross sections $(5 \mu \mathrm{m})$ were obtained in a microtome and stained with hematoxylineosin. Using an image analysis system, morphometry was conducted to determine the smallest diameter of 200 muscle fibers per animal. The data on diameter (D) were separated, as described in Assis et al. (2004), into the following classes: $\mathrm{c} 10, \mathrm{D} \leq 10 \mu \mathrm{m} ; \mathrm{c} 20,10<\mathrm{D} \leq$ $20 \mu \mathrm{m}$; c30, $20<\mathrm{D} \leq 30 \mu \mathrm{m}$; and c $40,30<\mathrm{D} \leq 40 \mu \mathrm{m}$. On the basis of the results of diameter classification, the degree of hypertrophic and hyperplastic growth of muscle fibers was evaluated according to AlamiDurante et al. (2010).

Data on zootechnical performance and histology were subjected to the analysis of variance, and the means were compared by the Tukey's test, at $5 \%$ probability. The best level of FPH inclusion was determined by a

Table 2. Composition of experimental diets based on plant ingredients with fish protein hydrolysate (FPH) inclusion for post-larvae of Nile tilapia (Oreochromis niloticus).

\begin{tabular}{|c|c|c|c|c|c|}
\hline \multirow[t]{2}{*}{ Ingredient } & \multicolumn{5}{|c|}{ FPH (\%) } \\
\hline & 0 & 2 & 4 & 6 & 8 \\
\hline Soybean meal & 39.79 & 39.26 & 39.29 & 39.19 & 39.21 \\
\hline Corn gluten & 25.10 & 24.31 & 23.07 & 21.12 & 21.10 \\
\hline Corn grain & 12.57 & 12.89 & 13.10 & 13.51 & 13.13 \\
\hline FPH & 0.00 & 2.00 & 4.00 & 6.00 & 8.00 \\
\hline Rice meal & 5.00 & 5.00 & 5.00 & 5.00 & 5.00 \\
\hline Wheat gluten & 5.00 & 5.00 & 5.00 & 5.00 & 5.00 \\
\hline Dicalcium phosphate & 3.85 & 3.84 & 3.82 & 3.81 & 3.80 \\
\hline Sobean protein isolate & 3.00 & 3.00 & 3.00 & 3.00 & 3.00 \\
\hline Supplement (mineral + vitamin) ${ }^{(1)}$ & 1.00 & 1.00 & 1.00 & 1.00 & 1.00 \\
\hline L-threonine & 0.23 & 0.22 & 0.22 & 0.21 & 0.21 \\
\hline Antifungal & 0.20 & 0.20 & 0.20 & 0.20 & 0.20 \\
\hline Soybean oil & 4.07 & 3.09 & 2.11 & 1.13 & 0.15 \\
\hline Vitamin C & 0.10 & 0.10 & 0.10 & 0.10 & 0.10 \\
\hline L-tryptophan & 0.06 & 0.06 & 0.05 & 0.05 & 0.05 \\
\hline DL-methionine & 0.01 & 0.01 & 0.02 & 0.02 & 0.03 \\
\hline Antioxidant & 0.02 & 0.02 & 0.02 & 0.02 & 0.02 \\
\hline Total & 100.00 & 100.00 & 100.00 & 100.00 & 100.00 \\
\hline \multicolumn{6}{|l|}{ Calculated values } \\
\hline Linoleic acid (\%) & 03.12 & 2.70 & 2.28 & 1.86 & 1.44 \\
\hline $\operatorname{Starch}(\%)$ & 21.40 & 21.41 & 21.41 & 21.41 & 21.41 \\
\hline Calcium (\%) & 1.10 & 1.10 & 1.10 & 1.10 & 1.10 \\
\hline DE tilapia $\left(\mathrm{kcal} \mathrm{kg}^{-1}\right)$ & 3,500 & 3,500 & 3,500 & 3,500 & 3,500 \\
\hline Fat $(\%)$ & 6.21 & 6.20 & 6.19 & 6.19 & 6.18 \\
\hline Methionine (\%) & 0.75 & 0.75 & 0.75 & 0.75 & 0.75 \\
\hline Digestible protein (\%) & 41.30 & 41.30 & 41.30 & 41.30 & 41.30 \\
\hline Threonine (\%) & 1.70 & 1.70 & 1.70 & 1.70 & 1.70 \\
\hline Tryptophan & 0.43 & 0.43 & 0.43 & 0.43 & 0.43 \\
\hline
\end{tabular}

${ }^{(1)}$ Guarantee levels per kilogram of product: 500,000 IU vitamin A; 200,000 IU vitamin D3; 5,000 mg vitamin E; 1,000 mg vitamin K3; 1,500 mg vitamin B1; 1,500 mg vitamin B2; 1,500 mg vitamin B6; 4,000 mg vitamin B12; 15,000 mg vitamin C; $50 \mathrm{mg}$ biotin; 7,000 mg nicotinamide; $500 \mathrm{mg}$ folic acid; 4,000 mg calcium pantothenate; 10,000 IU inositol; 40,000 mg choline; $10 \mathrm{mg} \mathrm{Co;} 500 \mathrm{mg} \mathrm{Cu} ; 5,000 \mathrm{mg} \mathrm{Fe;} 50 \mathrm{mg} \mathrm{I} ; 1,500 \mathrm{mg} \mathrm{Mn} ; 10 \mathrm{mg} \mathrm{Se} ;$ and 5,000 $\mathrm{mg} \mathrm{Zn}$. 
quadratic equation, associated with the linear response plateau (LRP) model. Data were calculated by the statistical software SAEG (Universidade Federal de Viçosa, Viçosa, MG, Brazil).

\section{Results and Discussion}

The centesimal composition showed that FPH had $40.74 \%$ crude protein, $54.06 \%$ lipids, $3.23 \%$ ash, and $6.429 \mathrm{kcal} \mathrm{kg}^{-1}$ of gross energy (values based on dry matter). These values are similar to other hydrolysates mentioned in the literature, produced with fish residues, such as: shrimp, with $46.7 \%$ crude protein (BuenoSolano et al., 2009); tilapia, with $37.7 \%$ crude protein (Abdul-Hamid et al., 2002); and croaker, with 47.09\% crude protein (Martins et al., 2009). The nature and quality of the raw material are two of the factors that can affect the results obtained from the composition, and that can affect characteristics as the quality and functionality of the final product (Choi et al., 2009).

The values for ADCs of crude protein, gross energy, fat, and dry matter were, respectively, 99.28, 99.13, 97.64, and 98.29\%. The high-protein digestibility may be associated with the increased solubility, and a structural unfolding of the protein molecule into smaller peptide units occurred during hydrolysis (Van Der Plancken et al., 2003). These smaller molecules, generated by the hydrolysis process, show considerably higher-intestinal absorption kinetics for solutions that contain only dipeptides and tripeptides, or partially hydrolyzed proteins, than those composed only of free amino acids (Fairclough et al., 1980; Zhanghi \& Mattews, 2010).

The speed of absorption of free amino acids and small peptides is attributed to factors such as competition between amino acids and the transport of amino acids. Free amino acids are rapidly absorbed only in the proximal small intestine, whereas dipeptides and tripeptides are absorbed in both the proximal and distal portions of the small intestine; dipeptides and tripeptides have a faster rate of absorption (Frenhani \& Burini, 1999; Ronnestad \& Morais, 2008).

In vivo digestibility of FPH is still rarely evaluated. However, in vitro digestibility shows slightly lower results than those found in the present study. Hevroy et al. (2005) found $95 \%$ dry matter, 98\% gross energy, and $91 \%$ lipids; and Foh et al. (2011) mentioned values of $93.2 \%$ protein digestibility.
The values of productive performance - final mass, mass gain, specific growth rate, and batch uniformity - showed a quadratic effect $(\mathrm{p}<0.05)$ with the FPH inclusion. However, survival was not affected $(p>0.05)$ by the experimental diets (Table 3 ). The association of the quadratic effect with the LRP model was adjusted only for the final mass, mass gain (indicating the same value), and specific growth rate, where the maximum inclusion determined were 4.75 and $4.77 \%$, respectively (Figure 1).
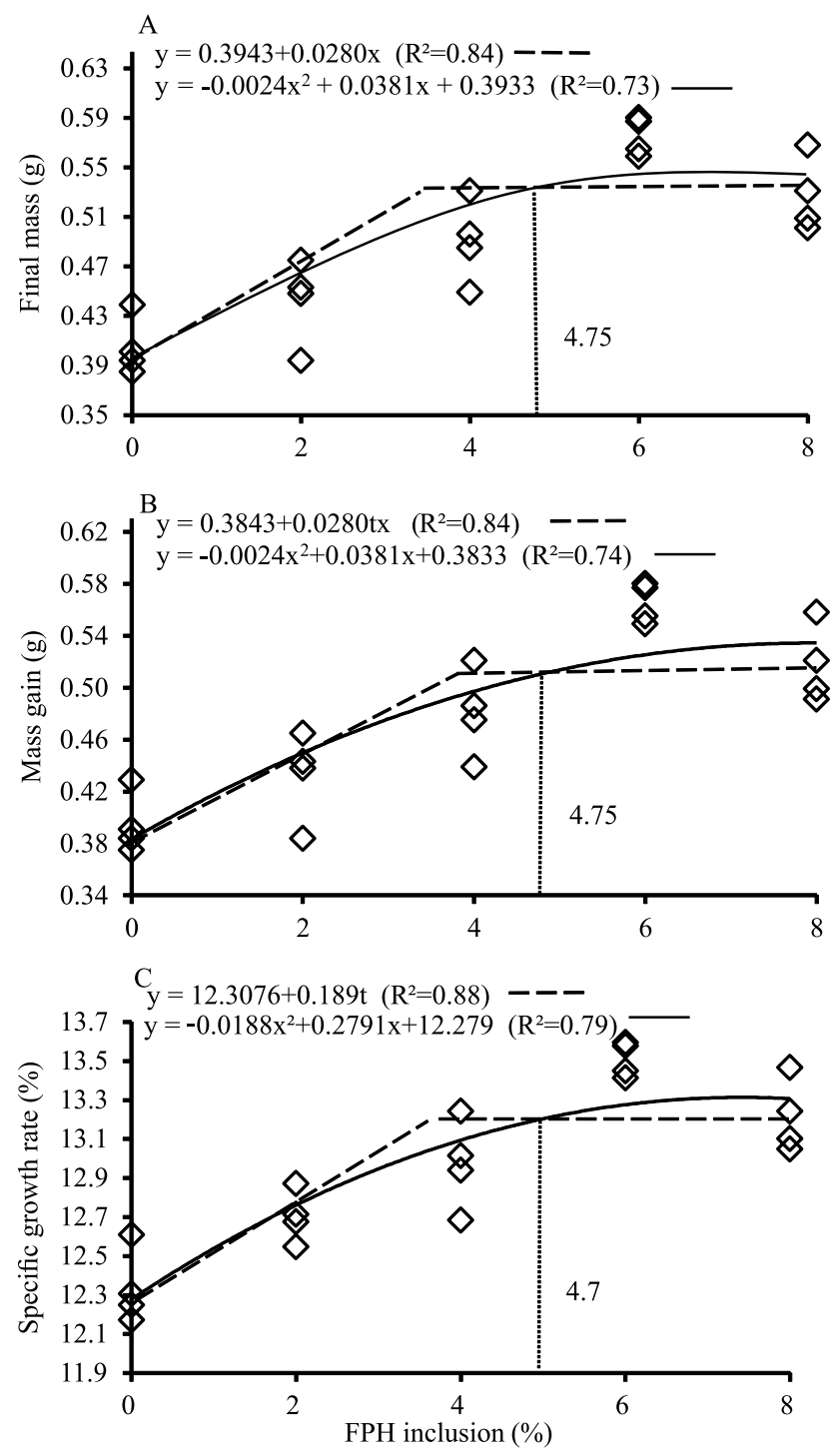

Figure 1. Best fish protein hydrolysate (FPH) inclusion level for final mass (A), mass gain (B), and specific growth rate $(\mathrm{C})$, by means of the first intercept of the quadratic equation with LRP plateau. 
Earlier studies have shown that diets supplemented with FPH can improve the productive performance of several fish species in the early stages of life(Kotzamanis et al., 2007; Tang et al., 2008; Chotikachinda et al., 2013). These findings are corroborated by the data obtained in the present study.

The main causes of the positive effect of FPH are associated with improved palatability and high digestibility of the protein, which stimulates digestive enzymes and channels nutrients for biomass production (Hevroy et al., 2005; Zheng et al., 2013). The positive effects on the growth rate and the final mass of salmon juveniles, fed on a diet containing 5 to $8 \% \mathrm{FPH}$, are mentioned by Berge \& Storebakken (1996). Likewise, Zheng et al. (2013) observed that flounder fed $3.7 \%$ FPH showed a better growth and feed efficiency. The inclusion of FPH above $50 \%$ may lead to a decrease of feed intake, which is caused by a change in the palatability of the hydrolysate due to bitter-tasting peptides or rancid lipid compounds, which result in decreased feed consumption and animal growth (Hevroy et al., 2005). The inclusion of FPH affected the frequency distribution of muscle fibers $(p<0.05)$, with a higher number of fibers with a diameter below $10 \mu \mathrm{m}$; and the treatment with $2 \%$ of FPH resulted in $74.06 \%$ fibers in this size class (Table 4). This indicates growth by hyperplasia, which is characterized by fiber diameters lower than $20 \mu \mathrm{m}$ (Rowlerson \& Veggetti, 2001; Johnston \& Hall, 2004).

The process of hyperplasia is predominant in the initial life stages of animals (Almeida et al., 2010); nevertheless, as indicated in the present study, factors such as nutrition may affect the dynamics of muscle fiber growth. With the increased FPH inclusion corresponding to the post-larvae mass gain, there was a frequency decrease in the c10 class muscle fiber and a consequent increase in the c20 class, that is, there was a negative correlation between mass gain and class $<10(-0.64)$, and a positive correlation for class c20 (0.62). In a study conducted with 35-day-old pacu post-larvae, Leitão et al. (2011) also show the effect of diet on the proportion of muscle fibers in hypertrophy and hyperplasia.

Table 3. Perfomance of post-larvae of Nile tilapia (Oreochromis niloticus) fed diets with different levels of fish protein hydrolysate $(\mathrm{FPH})$ inclusion.

\begin{tabular}{|c|c|c|c|c|c|c|c|}
\hline \multirow[t]{2}{*}{ Variable } & \multicolumn{5}{|c|}{ Fish protein hydrolysate inclusion (\%) } & \multirow{2}{*}{$\begin{array}{l}\text { Coeficient of } \\
\text { variation }(\%)\end{array}$} & \multirow[t]{2}{*}{$\mathrm{p}$-value } \\
\hline & 0 & 2 & 4 & 6 & 8 & & \\
\hline Final mass $(g)^{(1)}$ & $0.40 \pm 0.02$ & $0.44 \pm 0.03$ & $0.50 \pm 0.03$ & $0.57 \pm 0.01$ & $0.52 \pm 0.03$ & 18.84 & $<0.0001^{* *}$ \\
\hline Mass gain $(g)^{(2)}$ & $0.39 \pm 0.02$ & $0.42 \pm 0.03$ & $0.48 \pm 0.03$ & $0.56 \pm 0.01$ & $0.52 \pm 0.03$ & 13.61 & $<0.0001^{* *}$ \\
\hline Specific growth rate $(\%)^{(3)}$ & $12.33 \pm 0.19$ & $12.63 \pm 0.13$ & $12.97 \pm 0.23$ & $13.51 \pm 0.09$ & $13.21 \pm 0.19$ & 3.34 & $0.0180 *$ \\
\hline Batch uniformity $(\%)^{(4)}$ & $65.62 \pm 3.15$ & $72.54 \pm 5.52$ & $77.12 \pm 4.34$ & $74.48 \pm 2.17$ & $66.62 \pm 4.33$ & 8.63 & $0.0003 * *$ \\
\hline Survival $(\%)^{(5)}$ & $88.33 \pm 6.38$ & $83.33 \pm 6.66$ & $90.00 \pm 11.57$ & $90.00 \pm 0.67$ & $86.67 \pm 10.88$ & 9.08 & $0.8385^{\mathrm{ns}}$ \\
\hline
\end{tabular}

(1) Final mass (quadratic effect, $\mathrm{FM}=-0.024 \mathrm{t}^{2}+0.381 \mathrm{t}+0.3933, \mathrm{R}^{2}=73$ ). (2) Mass gain (quadratic effect, $\mathrm{MG}=-0.0024 \mathrm{t}^{2}+0.0381 \mathrm{t}+0,3833, \mathrm{R}^{2}=0,74$ ). ${ }^{(3)}$ Specific growth rate (quadratic effect, $\mathrm{SGR}=-0.0188 \mathrm{t}^{2}+0.2791 \mathrm{t}+12.279, \mathrm{R}^{2}=0,79$ ). ${ }^{\left({ }^{4}\right)}$ Batch uniformity (quadratic effect, $\mathrm{BU}=-0.6537 \mathrm{t}^{2}+5.1505 \mathrm{t}+$ 63.892, $\mathrm{R}^{2}=52$ ). ${ }^{(5)}$ Survival (no effect). ${ }^{\mathrm{n}}$ Nonsignificant. * and $* *$ Significant at 5 and $1 \%$ probability, respectively.

Table 4. Occurrence frequency of white muscle fibers in diameter classes - c10 $(<10), \mathrm{c} 20(10-20), \mathrm{c} 30(20-30)$, and c40 $(>30)$-, in post-larvae of Nile tilapia (Oreochromis niloticus) diets with different levels of fish protein hydrolysate (FPH) inclusion.

\begin{tabular}{|c|c|c|c|c|c|c|c|}
\hline \multirow{2}{*}{$\begin{array}{l}\text { Diameter class } \\
(\mu \mathrm{m})\end{array}$} & \multicolumn{5}{|c|}{ Fish protein hydrolysate inclusion (\%) } & \multirow{2}{*}{$\begin{array}{l}\text { Coeficient of } \\
\text { variation }(\%)\end{array}$} & \multirow[t]{2}{*}{$\mathrm{p}$-value } \\
\hline & 0 & 2 & 4 & 6 & 8 & & \\
\hline $\mathrm{cl0}$ & $58.25 \mathrm{ab}$ & $74.06 \mathrm{~b}$ & $68.38 \mathrm{ab}$ & $60.87 \mathrm{ab}$ & $51.83 \mathrm{a}$ & 20.76 & $0.0225^{*}$ \\
\hline $\mathrm{c} 20$ & 41.75 & 25.94 & 31.56 & 38.36 & 44.41 & 34.99 & $0.0580^{\mathrm{ns}}$ \\
\hline $\mathrm{c} 30$ & $0.00 \mathrm{a}$ & $0.00 \mathrm{a}$ & $0.06 \mathrm{a}$ & $0.71 \mathrm{a}$ & $3.34 b$ & 76.90 & $<0.0001^{* *}$ \\
\hline $\mathrm{c} 40$ & $0.00 \mathrm{a}$ & $0.00 \mathrm{a}$ & $0.00 \mathrm{a}$ & $0.06 \mathrm{a}$ & $0.42 \mathrm{a}$ & 11.73 & $0.0002 * *$ \\
\hline
\end{tabular}

${ }^{n s}$ Nonsignificant. * and $* *$ Significant at 5 and $1 \%$ probability, respectively. 


\section{Conclusions}

1. The apparent digestibility of crude protein (99.28\%), fat (99.13\%), dry matter (97.64\%), and energy utilization $(98.29 \%)$ show that the fish protein hydrolysate can be used efficiently by Nile tilapia (Oreochromis niloticus).

2. The growth of muscle fibers is characterized by hyperplasia.

3. The inclusion of the fish protein hydrolysate at $4.75 \%$ is indicated in diets for Nile tilapia, in the post-larval phase.

\section{Acknowledgments}

To Fundação Araucária, for financial support.

\section{References}

ABDUL-HAMID, A.; BAKAR, J.; BEE, G.H. Nutritional quality of spray dried protein hydrolysate from black tilapia (Oreochromis mossambicus). Food Chemistry, v.78, p.69-74, 2002. DOI: 10.1016/S0308-8146(01)00380-6.

ALAMI-DURANTE, H.; MÉDALE, F.; CLUZEAUD, M.; KAUSHIK, S.J. Skeletal muscle growth dynamics and expression of related genes in white and red muscles of rainbow trout fed diets with graded levels of a mixture of plant protein sources as substitutes for fishmeal. Aquaculture, v.303, p.50-58, 2010. DOI: 10.1016/j.aquaculture.2010.03.012.

ALMEIDA, F.L. de A.; PESSOTTI, N.S.; PINHAL, D.; PADOVANI, C.R.; LEITÃO, N.de J.; CARVALHO, R.F.; MARTINS, C.; PORTELLA, M.C.; DAL PAI-SILVA, M. Quantitative expression of myogenic regulatory factors MyoD and myogenin in pacu (Piaractus mesopotamicus) skeletal muscle during growth. Micron, v.41, p.997-1004, 2010. DOI: 10.1016/j. micron.2010.06.012.

ASSIS, J.M.F. de; CARVALHO, R.F.; BARBOSA, L.; AGOSTINHO, C.A.; DAL PAI-SILVA, M. Effects of incubation temperature on muscle morphology and growth in the pacu (Piaractus mesopotamicus). Aquaculture, v.237, p.251-267, 2004. DOI: 10.1016/j.aquaculture.2004.04.022.

BERGE, G.M.; STOREBAKKEN, T. Fish protein hydrolyzate in starter diets for Atlantic salmon (Salmo salar) fry. Aquaculture, v.145, p.205-212, 1996. DOI: 10.1016/S0044-8486(96)01355-5.

BREMER NETO, H.; GRANER, C.A.F.; PEZZATO, L.E.; PADOVANI, C.R.; CANTELMO O.A. Diminuição do teor de óxido de crômio (III) usado como marcador externo. Revista Brasileira de Zootecnia, v.32, p.249-255, 2003. DOI: 10.1590/ S1516-35982003000200001.

BROGGI, J.A. Hidrolisado proteico de sardinha (Clupeidae) como atrativo alimentar para o jundiá (Rhamdia quelen). 2014. 49p. Dissertação (Mestrado) - Universidade do Estado de Santa Catarina, Lages.
BUENO-SOLANO, C.; LÓPEZ-CERVANTES, J.; CAMPASBAYPOLI, O.N.; LAUTERIO-GARCÍA, R.; ADAN-BANTE, N.P.; SÁNCHEZ-MACHADO, D.I. Chemical and biological characteristics of protein hydrolysates from fermented shrimp byproducts. Food Chemistry, v.112, p.671-675, 2009. DOI: 10.1016/j. foodchem.2008.06.029.

CHOI, Y.J.; HUR, S.; CHOI, B.-D.; KONNO, K.; PARK, J.W. Enzymatic hydrolysis of recovered protein from frozen small croaker and functional properties of its hydrolysates. Journal of Food Science, v.74, p.C17-C24, 2009. DOI: 10.1111/j.17503841.2008.00988.x.

CHOTIKACHINDA, R.; TANTIKITTI, C.; BENJAKUL, S.; RUSTAD, T.; KUMARNSIT, E. Production of protein hydrolysates from skipjack tuna (Katsuwonus pelamis) viscera as feeding attractants for Asian seabass (Lates calcarifer). Aquaculture Nutrition, v.19, p.773-784, 2013. DOI: 10.1111/ anu.12024.

FAIRCLOUGH, P.D.; HEGARTY, J.E.; SILK, D.B.; CLARK, M.L. Comparison of the absorption of two protein hydrolysates and their effects on water and electrolyte movements in the human jejunum. Gut, v.21, p.829-834, 1980.

FOH, M.B.K.; KAMARA, M.T.; AMADOU, I.; FOH, B.M.; WENSHUI, X. Chemical and physicochemical properties of tilapia (Oreochromis niloticus) fish protein hydrolysate and concentrate. International Journal of Biological Chemistry, v.5, p.21-36, 2011. DOI: 10.3923/ijbc.2011.21.36.

FRENHANI, P.B.; BURINI, R.C. Mecanismos de ação e controle da digestão de proteínas e peptídios em humanos. Arquivos de Gastroenterologia, v.36, p.139-147, 1999.

GALDIOLI, E.M.; HAYASHI, C.; SOARES, C.M.; FURUYA, W.M.; NAGAE, M.Y. Diferentes fontes protéicas na alimentação de alevinos de curimba (Prochilodus lineatus, V.). Acta Scientiarum, v.22, p.471-477, 2000. DOI: 10.4025/actascibiolsci. v22i0.2930.

HEVROY, E.M.; ESPE, M.; WAAGB, R.; SANDNES, K.; RUUD, M.; HEMRE, G.-I. Nutrient utilization in Atlantic salmon (Salmo salar L.) fed increased levels of fish protein hydrolysate during a period of fast growth. Aquaculture Nutrition, v.11, p.301-313, 2005. DOI: 10.1111/j.1365-2095.2005.00357.x.

HORWITZ, W. (Ed.). Official Methods of Analysis of the AOAC International. $18^{\text {th }}$ ed. Gaithersburg: Association of Official Analytical Chemists, 2005.

JOHNSTON, I.A.; HALL, T.E. Mechanisms of muscle development and responses to temperature change in fish larvae. American Fisheries Society Symposium, v.40, p.85-116, 2004.

KOTZAMANIS, Y.P.; GISBERT, E.; GATESOUPE, F.J.; ZAMBONINO INFANTE, J.L.; CAHU, C. Effects of different dietary levels of fish protein hydrolysates on growth, digestive enzymes, gut microbiota, and resistance to Vibrio anguillarum in European sea bass (Dicentrarchus labrax) larvae. Comparative Biochemistry and Physiology. Part A: Molecular and Integrative Physiology, v.147, p.205-214, 2007. DOI: 10.1016/j. cbpa.2006.12.037.

LEITÃO, N. de J.; DAL PAI-SILVA, M.; ALMEIDA, F.L.A. de; PORTELLA, M.C. The influence of initial feeding 
on muscle development and growth in pacu Piaractus mesopotamicus larvae. Aquaculture, v.315, p.78-85, 2011. DOI: 10.1016/j.aquaculture.2011.01.006.

LIAN, P.Z.; LEE, C.M.; PARK, E. Characterization of squidprocessing byproduct hydrolysate and its potential as aquaculture feed ingredient. Journal of Agricultural and Food Chemistry, v.53, p.5587-5592, 2005. DOI: 10.1021/jf050402w.

MARTINS, V.G.; COSTA, J.A.V.; PRENTICE-HERNÁNDEZ, C. Hidrolisado protéico de pescado obtido por vias química e enzimática a partir de corvina (Micropogonias furnieri). Química Nova, v.32, p.61-66, 2009. DOI: 10.1590/S010040422009000100012.

MERINO, G.; BARANGE, M.; MULLON, C. Climate variability and change scenarios for a marine commodity: modelling small pelagic fish, fisheries and fishmeal in a globalized market. Journal of Marine Systems, v.81, p.196-205, 2010. DOI: 10.1016/j. jmarsys.2009.12.010.

NAYLOR, R.L.; HARDY, R.W.; BUREAU, D.P.; CHIU, A.; ELLIOTT, M.; FARRELL, A.P.; FORSTER, I.; GATLIN, D.M.; GOLDBURG, R.J.; HUA, K.; NICHOLS, P.D. Feeding aquaculture in an era of finite resources. Proceedings of the National Academy of Sciences of the United States of America, v.106, p.15103-15110, 2009. DOI: 10.1073/pnas.0905235106.

NILSANG, S.; LERTSIRI, S.; SUPHANTHARIKA, M.; ASSAVANIG, A. Optimization of enzymatic hydrolysis of fish soluble concentrate by commercial proteases. Journal of Food Engineering, v.70, p.571-578, 2005. DOI: 10.1016/j. jfoodeng.2004.10.011.

NRC. National Research Council. Nutrient requirements of fish and shrimp. Washington: National Academies Press, 2011. 379p.

PASUPULETI, V.K.; BRAUN, S. State of the art manufacturing of protein hydrolysates. In: PASUPULETI, V.K.; DEMAIN, A.L. (Ed.). Protein hydrolysates in biotechnology. Dordrecht: Springer, 2010. p.11-32. DOI: 10.1007/978-1-4020-6674-0_2.

PHELPS, R.P. Recent advances in fish hatchery management. Revista Brasileira de Zootecnia, v.39, p.95-101, 2010. DOI: 10.1590/S1516-35982010001300011.

REFSTIE, S.; OLLI, J.J.; STANDAL, H. Feed intake, growth, and protein utilisation by post-smolt Atlantic salmon (Salmo salar) in response to graded levels of fish protein hydrolysate in the diet. Aquaculture, v.239, p.331-349, 2004. DOI: 10.1016/j. aquaculture.2004.06.015.
RIDHA, M.T.; CRUZ, E.M. Effect of biofilter media on water quality and biological performance of the Nile tilápia Oreochromis niloticus L. reared in a simple recirculating system. Aquacultural Engineering, v.24, p.157-166, 2001. DOI: 10.1016/ S0144-8609(01)00060-7.

RONNESTAD, I.; MORAIS, S. Digestion. In: FINN, R.N.; KAPOOR, B.G. Fish larval physiology. Enfield: Science Publishers, 2008. p.201-262.

ROWLERSON, A.; VEGGETTI, A. Cellular mechanisms of post-embryonic muscle growth in aquaculture species. In: JOHNSTON, A.I. (Ed.). Muscle development and growth. San Diego: Academic Press, 2001. p.101-130. DOI: 10.1016/S15465098(01)18006-4.

TACON, A.G.J.; METIAN, M. Global overview on the use of fish meal and fish oil in industrially compounded aquafeeds: trends and future prospects. Aquaculture, v.285, p.146-158, 2008. DOI: 10.1016/j.aquaculture.2008.08.015.

TANG, H.; WU, T.; ZHAO, Z.; PAN, X. Effects of fish protein hydrolysate on growth performance and humoral immune response in large yellow croaker (Pseudosciaena crocea R.). Journal of Zhejiang University Science B, v.9, p.684-690, 2008. DOI: 10.1631/jzus.B0820088.

TEIXEIRA, E. de A.; CREPALDI, D.V.; FARIA, P.M.C.; RIBEIRO, L.P.; MELO, D.C.; EULER, A.C.C.; SALIBA, E. de O.S. Substituição de farinha de peixes em rações para peixes. Revista Brasileira de Reprodução Animal, v.30, p.118-125, 2006.

VAN DER PLANCKEN, I.; VAN REMOORTERE, M.; INDRAWATI, I.; VAN LOEY, A.; HENDRICKX, M.E. Heatinduced changes in the susceptibility of egg white proteins to enzymatic hydrolysis: kinetic study. Journal of Agricultural and Food Chemistry, v.51, p.3819-3823, 2003. DOI: 10.1021/ jf026019y.

ZHANGHI, B.M.; MATTHEWS, J.C. Physiological importance and mechanisms of protein hydrolysate absorption. In: PASUPULETI, V.K.; DEMAIN, A.L. (Ed.). Protein hydrolysates in Biotechnology. Dordrecht: Springer, 2010. p.135-177.

ZHENG, K.; LIANG, M.; YAO, H.; WANG, J.; CHANG, Q. Effect of size-fractionated fish protein hydrolysate on growth and feed utilization of turbot (Scophthalmus maximus L.). Aquaculture Research, v.44, p.895-902, 2013. DOI: 10.1111/j.13652109.2012.03094.x.

Received on February 26, 2016 and accepted on October 20, 2016

Pesq. agropec. bras., Brasília, v.52, n.7, p.485-492, jul. 2017

DOI: $10.1590 / \mathrm{S} 0100-204 X 2017000700002$ 